\title{
Genetic divergence of soybean genotypes in relation to grain components
}

\section{Josiane Isabela da Silva Rodrigues ${ }^{1 *}$ Klever Márcio Antunes Arruda ${ }^{2}$ Cosme Damião Cruz ${ }^{1}$ Everaldo Gonçalves de Barros $^{3}$ Newton Deniz Piovesan ${ }^{1}$ Maurilio Alves Moreira ${ }^{4}$}

\footnotetext{
${ }^{1}$ Instituto de Biotecnologia Aplicado à Agropecuária, Universidade Federal de Viçosa (UFV), Campus Universitário, Avenida PH Rolfs, 36570-000, Viçosa, MG, Brasil. E-mail: josianeisabela@gmail.com. "Corresponding author.

${ }^{2}$ Instituto Agronômico do Paraná, Londrina, PR, Brasil.

${ }^{3}$ Programa de Pós-graduação em Ciências Genômicas e Biotecnologia, Universidade Católica de Brasília (UCB), Brasília, DF, Brasil.

${ }^{4}$ In memoriam.
}

\begin{abstract}
The objective of this paper was to estimate the genetic divergence among 49 soybean (Glycine max L. Merrill.) genotypes to assist grain quality-focused breeding programs in the choice of progenitors. The genetic divergence was estimated using the Mahalanobis generalized distance from the percentages of protein, oil, and fatty acids oleic, linoleic and linolenic after cultivation of genotypes in different environments. Genotypes were grouped by agglomerative methods and the two and three-dimensional projections of the distance matrix were obtained. The average protein and oil contents in the four environments ranged from 34.25 to $45.18 \%$ and from 16.48 to $23.01 \%$, respectively. The average contents of the fatty acids oleic, linoleic and linolenic ranged from 20.2 to $42.41 \%$, from 44.17 to $63.18 \%$, and from 5.89 to $10.39 \%$, respectively. The genetic distances ranged from 0.11 to 251.02 and indicated genetic variability among the accessions. The most divergent pair of accessions was PI417360/CD01RR8384, followed by PI417360/B3PTA213-3-4 and PI417360/BARC-8. The most similar par of accessions was CS3032PTA276-1-2/CS3032PTA190-5-1, followed by UFV18/M-SOY8914 and BRSMG Garantia/CD983321RR. In this study we indicated as promising in terms of genetic variability the hybridizations involving BARC-8, CD2013PTA, CD01RR8384, CS303TNKCA, PI181544, and PI417360. Among these genotypes we can stand out BARC-8 and CD2013PTA, with protein contents above 43\%, and CD01RR8384 and CS303TNKCA, with oil contents above $20 \%$. The use of these genetically divergent genotypes and with high phenotypic means in future crosses should produce desirable recombinants for grain quality.
\end{abstract} Key words: Glycine max L. Merrill., protein, oil, fatty acids.

\section{Divergência genética de genótipos de soja quanto a componentes do grão}

RESUMO: O objetivo deste trabalho foi estimar a divergência genética entre 49 genótipos de soja (Glycinemax L. Merrill.), visando auxiliar programas de melhoramento voltados à qualidade do grão na escolha de progenitores. A divergência genética foi estimada por meio da distância generalizada de Mahalanobis a partir dos percentuais de proteina, óleo e ácidos graxos oleico, linoleico e linolênico após cultivo dos genótipos em diferentes ambientes. Os genótipos foram agrupados por métodos aglomerativos e as projeções bi e tridimensional da matriz de distância foram obtidas. Os teores médios de proteína é óleo nos quatro ambientes variaram de 34,25 a 45,18\% e de 16,48 a 23,01\%, respectivamente. Os teores médios dos ácidos graxos oleico, linoleico e linolênico variaram de 20,2 a 42,41\%, de 44,17 a 63,18\% e de 5,89 a 10,39\%, respectivamente. As distâncias genéticas variaram de 0,11 a 251,02 e indicaram variabilidade genética entre os acessos. O par de acessos mais divergente foi PI417360/CD01RR8384, seguido por PI417360/ B3PTA213-3-4 e PI417360/BARC-8. Já o par de acessos mais similar foi CS3032PTA276-1-2/CS3032PTA190-5-1, seguido por UFV18/M-SOY8914 e BRSMG Garantia/CD983321RR. Neste estudo, são indicadas como promissoras em termos de variabilidade genética as hibridações envolvendo BARC-8, CD2013PTA, CD01RR8384, CS303TNKCA, PI181544 e PI417360. Dentre esses genótipos, destacam-se BARC-8 e CD2013PTA, com teores proteicos acima de 43\%, e CD01RR8384 e CS303TNKCA, com teores de óleo acima de 20\%. A utilização desses genótipos geneticamente divergentes e com elevadas médias fenotípicas em futuros cruzamentos deverá produzir recombinantes desejáveis para a qualidade do grão.

Palavras-chave: Glycinemax L. Merrill., proteína, óleo, ácidos graxos.

\section{INTRODUCTION}

Soybean has prospect of improvement for oil and protein contents and for grain oil composition, because a small fraction of its germplasm constitutes the genetic basis of improved cultivars. Historically the use of elite materials maintained narrow the genetic basis of improved varieties.

In the 80 decade, $15 \%$ of the cultivated soybean in Brazil were introduced in the southern region of the United States and the remaining $85 \%$ came from hybridization of the North American introductions (VELLO et al., 1988). According to HIROMOTO \&
VELLO (1986), 79 cultivars recommended at that time descended from 26 ancestors of which 11 formed $89 \%$ of the gene pool.VELLO et al. (1988) at the same time observed an average relatedness value of 0.16 between 69 soybean cultivars, the equivalent to an effective size equal to $\mathrm{N}=11-15$. Other 100 cultivars released between 1984 and 1998, showing an average relatedness value equal to 0.21 (BONATO et al., 2006). Equal relatedness value and effective size equal to $\mathrm{N}=11$ are reported by MIRANDA et al. (2007) among 90 elite cultivars. According to the authors, the low values of effective size and high estimates of relatedness reflect a high similarity among the cultivars. In the same way, also in 
studies with molecular markers it is clear the similarity among the Brazilian cultivars (VIEIRA et al., 2009; PRIOLLI et al., 2010). Thus, a relatively low level of diversity is maintained in different breeding programs, although there is some heterogeneity in a minority of the programs, according to PRIOLLI et al. (2004).

Due to the limited genetic diversity in soybean elite germplasm and to the relative lack of variability in breeding programs, the use of new sources of germplasm can be useful to broaden the genetic basis of breeding programs and to enable the new cultivars additional gains in the protein and oil contents or improvement in oil fraction. The objective of this research was to estimate the genetic divergence among 49 soybean genotypes, based on the protein, oil and fatty acids contents in order to help breeding programs focused on quality in the choice of progenitors.

Several multivariate methods can be used to estimate genetic divergence. The methods of principal components and canonical variables seek to evaluate the similarity through a graphic dispersion, being usually two Cartesian axes. The agglomerative methods are based on the use of dissimilarity measures as the Euclidean distance and Mahalanobis generalized distance, etc. Among the most used ones, the mean standardized Euclidean distance circumvents problems due to the number and scale of the variables, but with the inconvenient of not taking into account the residual correlations. The Mahalanobis distance takes into account the correlation between the characters which is advantageous because most of the time there is a certain degree of correlation between the agronomic traits. The advantage of these methods in relation to the dialelic analyses is that they do not require hybrid combinations. In hybridization, manual pollination can be costly, difficult to perform with low probability of success in obtaining the hybrid seed, or even the hybrid seed that can be obtained in a very small quantity for proper evaluations. Then the predictive methods are faster and simpler to apply.

\section{MATERIALS AND METHODS}

Forty-nine soybean genotypes for which we expected a wide variation in oil and protein contents, according to preliminary analyses, were cultivated in Viçosa, MG (12/2009, $\left.20^{\circ} 45^{\prime} \mathrm{S}, 42^{\circ} 52^{\prime} \mathrm{W}\right)$, Visconde do Rio Branco, MG (02/2010, 21 $\left.1^{\circ} 00^{\prime} \mathrm{S}, 42^{\circ} 50^{\prime} \mathrm{W}\right)$ and São Gotardo, MG (02/2010, 10/2011, 19¹8' S, $\left.46^{\circ} 02^{\prime} \mathrm{W}\right)$ using the randomized block design with three replicates. In each trial conducted in the field we sown 15 seeds per $1 \mathrm{~m}$ length row with spacing between rows of $0.5 \mathrm{~m}$. The harvest was done manually and after beneficiation the grains were ground in an industrial mill (model MA020, Marconi, Brazil). The bran was analyzed for protein, oil and fatty acids oleic, linoleic and linolenic contents by the infrared spectrometry method using a FT-NIR spectrometer (model II Antaris, Thermo Scientific). For analysis of phenotypic data we performed analysis of variance based on the factorial design using the statistical model below:

$\mathrm{Y}_{\mathrm{ijk}}=\mu+\mathrm{G}_{\mathrm{i}}+\mathrm{E}_{\mathrm{j}}+\mathrm{GE}_{\mathrm{ij}}+\mathrm{B} / \mathrm{E}+\varepsilon_{\mathrm{ijk}}$

In which: $Y_{\mathrm{ijk}}$ : observation of the k-th block evaluated in the $\mathrm{i}$-th genotype and $\mathrm{j}$-th environment; m: general mean; $B / E_{j k}$ : effect of the block $k$ within the environment $j ; G_{i}$ : effect of the genotype $i ; E_{j}$ : effect of the environment $\mathrm{j}$; $\mathrm{GE}_{\mathrm{ij}}$ : effect of the interaction between genotype $\mathrm{i}$ and environment $\mathrm{j}$; and $\varepsilon_{\mathrm{ijk}}$ : random error associated with ijk observation. The effect of genotypes $\left(G_{i}\right)$ was considered fixed and the effect of environments $\left(E_{j}\right)$ was considered random. The variance components were estimated as follows:

$\emptyset_{\mathrm{g}}=\frac{\mathrm{QMG}-\mathrm{QMGE}}{\mathrm{er}}$

$\sigma_{\text {ga }}^{2}=\frac{(Q M G E-Q M R)}{r} 1$

In which: MSG is the mean square of genotypes; MSGE is the mean square of GE interaction; MSR is the mean square of residue; $\mathrm{e}$ is the number of environments; $r$ is the number of replicates; and in which $g$ is the number of genotypes.

We used the Mahalanobis gener,GMA, Tocher, and modified Tocher. The Mojema method (MOJEMA, 1977) and value of $\mathrm{k}=1.25$ were used as criteria to identify the cut off values from the dendrogram. The consistency of the grouping pattern was evaluated by bootstrap using 5.000 simulations. The importance of variables in determining the distance values among the pairs of accessions was evaluated by the Singh method (SINGH, 1981). All analyses were performed using the GENES program $<$ http://www.ufv.br/dbg/genes/>.

\section{RESULTS AND DISCUSSION}

Analyses of variance revealed significant differences among the 49 soybean genotypes in relation to protein, oil and fatty acids oleic, linoleic and linolenic contents. Coefficients of variation were below 5\% and demonstrated precision in controlling the causes of experimental variation. Based on the ratio between the highest and lowest residual mean square there was also homogeneity in residual variances. Effects of genotype, environment and GE interaction were 
significant $(\mathrm{P}<0.01)$ for the five traits, indicating genetic variability among the accessions, difference among the environments and differential behavior of the accessions in the environments. The effects of environments had the highest contributions to variation in the characters in relation to the other main effects. Results of the analyses of variance are presented in table 1.

The average protein and oil contents in the four environments ranged from 34.25 to $45.18 \%$ and from 16.48 to $23.01 \%$, respectively. The average contents of the fatty acids oleic, linoleic and linolenic ranged from 20.2 to $42.41 \%$, from 44.17 to $63.18 \%$ and from 5.89 to $10.39 \%$, respectively. Among the environments, the variation in the average percentages of protein and oil was from 32.07 to $48.57 \%$ and from 14.40 to $24.20 \%$, respectively. The variation in the average percentages of the acids oleic, linoleic and linolenic was from 16.38 to $57.35 \%$, from 29.56 to $69.51 \%$, and from 4.27 to $11.54 \%$, respectively. These values confirmed a wide variation among the accessions in relation to each component of the grain, as it was expected for the protein and oil contents (Table 2).

The Mahalanobis distances from the variation in the components of the grains ranged from 0.11 to 251.02 and indicated genetic variability among the accessions. The most divergent pair of accessions was PI417360/CD01RR8384, followed by PI417360/B3PTA213-3-4 and PI417360/ BARC-8. The most similar pair of accessions was CS3032PTA276-1-2/CS3032PTA190-5-1, followed by UFV18/M-SOY8914 and BRSMG Garantia/ CD983321RR. Regarding the importance of the variables to genetic diversity, the contribution of each variable to genetic diversity was equal to 33.28 , $20.81,20.85,13.54$, and $11.52 \%$ for the protein, oil and fatty acids oleic, linoleic and linolenic contents, respectively, revealing that protein content is the most informative character and acid linolenic content the less informative character. However the five variables had good contribution to be kept in the analysis.

The grouping by the Tocher method differentiated PI417360 in relation to all other 48 accessions, which were gathered in a single group. The modified method produced an identical grouping, which highlights the genetic distance of this accession in relation to the others. In the grouping by the UPGMA method, PI417360 proved to be the most divergent accession again, followed by PI181544. The accessions with the initials CS3032PTA proved to be close to each other as well as the accessions with the initials B3PTA. All the cultivars with the initials CS were close to each other in the projection, except CS303TNKCA. The accessions BARC-8 and BR8014887 proved to be very close to the previous genotypes, indicating elevated genetic similarity between all of them. Other genotypes showed to be genetically close to each other, as PI371610 and PI371611, most cultivars with the initials CD, except CD2013PTA and CD01RR8384, and the cultivars with the initials UFV and M-SOY. Cultivars A7002 and Suprema also showed a high degree of genetic similarity. The cultivar CD01RR8384, conversely, showed certain genetic divergence in relation to the previous ones. Most of the time there was greater proximity among cultivars of breeding programs of the same institution, which was expected. The values of cophenetic correlation, distortion and stress in the projection were equal to 0.95 , $6.89 \%$ and $26.25 \%$, respectively, which indicated good adjustment of the original and graphic values and small distortion of the distances in the dendrogram (Figure 1).

Thestatistical criterion of Mojema(MOJEMA, 1977), based on the relative size of the fusion levels in the dendrogram, provides the possibility of making cuts in different stages of the grouping for groups definition. A cut performed at $18.56 \%$ of the dissimilarity establishes the same relationship observed in the grouping by the Tocher method. while a cut at $7.31 \%$ of the dissimilarity

Table 1 - Analysis of variance of the protein, oil and fatty acids oleic, linoleic and linolenic contents of the 49 soybean genotypes cultivated in Viçosa-MG (12/2009), Visconde do Rio Branco-MG (02/2010) and São Gotardo-MG (02/2010, 10/2011).

\begin{tabular}{|c|c|c|c|c|c|c|}
\hline \multirow{2}{*}{ Source of variation } & \multirow{2}{*}{$\mathrm{DF}$} & \multicolumn{5}{|c|}{ 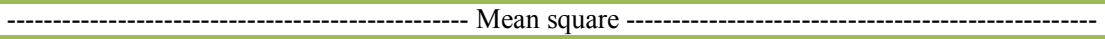 } \\
\hline & & Protein $(\%)$ & Oil (\%) & Oleic acid (\%) & Linoleic acid (\%) & Linolenic acid (\%) \\
\hline Blocks/Environments & 8 & 11.73 & 8.31 & 60.91 & 97.68 & 2.46 \\
\hline Genotypes & 48 & $89.22^{* *}$ & $30.39^{* *}$ & $128.98^{* *}$ & $129.24^{* *}$ & $8.30^{* *}$ \\
\hline Environments & 3 & $236.44^{* *}$ & $63.53^{* *}$ & $938.29^{* *}$ & $635.71^{* *}$ & $28.62^{* *}$ \\
\hline GE & 144 & $6.56^{* *}$ & $3.80^{* *}$ & $31.39^{* *}$ & $31.22^{* *}$ & $1.63^{* *}$ \\
\hline Error & 384 & 2.00 & 0.82 & 4.73 & 7.23 & 0.66 \\
\hline Mean & - & 39.67 & 19.51 & 23.90 & 59.42 & 8.99 \\
\hline $\mathrm{CV}(\%)$ & - & 3.56 & 4.64 & 9.10 & 4.52 & 9.04 \\
\hline Higher/LowerMSR & - & 3.77 & 3.50 & 1.80 & 1.37 & 4.05 \\
\hline $\mathrm{CVg} / \mathrm{CVe}$ & - & 1.86 & 1.64 & 1.31 & 1.06 & 0.92 \\
\hline
\end{tabular}

${ }^{* *}$ Significant at $1 \%$ probability by the F test; DF, degree of freedom; MSR, residual mean square; CVg, coefficient of genetic variation; CVe, coefficient of environmental variation. 
Table 2 - Average percentages of protein, oil and fatty acids oleic, linoleic and linolenic of the soybean genotypes in the four environments (Viçosa-MG 12/2009,Visconde do Rio Branco- MG 02/2010, São Gotardo-MG 02/2010, São Gotardo-MG 10/2011).

\begin{tabular}{|c|c|c|c|c|c|}
\hline Genotype & Protein (\%) & Oil (\%) & Oleic acid $(\%)$ & Linoleic acid (\%) & Linolenic acid(\%) \\
\hline 1-BRSMG Garantia & 38.82 & 19.74 & 25.64 & 57.31 & 9.21 \\
\hline 2-FMT Tucunaré & 37.56 & 20.82 & 22.51 & 59.42 & 8.76 \\
\hline 3-BRSGO Luziânia & 39.16 & 19.42 & 22.56 & 61.55 & 9.85 \\
\hline $4-U F V-16$ & 38.47 & 19.85 & 23.76 & 60.03 & 10.24 \\
\hline 5-CS3032PTA182 & 41.84 & 17.91 & 21.57 & 63.18 & 8.71 \\
\hline 6-BRS Sambaíba & 37.55 & 19.60 & 22.64 & 58.50 & 9.19 \\
\hline 7-CS94731 & 40.71 & 18.27 & 20.20 & 63.03 & 10.39 \\
\hline 8-M-SOY 8914 & 37.26 & 20.57 & 23.37 & 57.42 & 9.48 \\
\hline 9-UFV 18 & 37.72 & 20.43 & 23.37 & 57.86 & 9.17 \\
\hline 10-M-SOY 8400 & 39.26 & 18.81 & 25.42 & 57.50 & 8.89 \\
\hline 11-DM - 339 & 39.26 & 18.76 & 25.77 & 58.78 & 8.98 \\
\hline 12-UFVS 2012 & 37.15 & 20.74 & 20.72 & 61.21 & 9.42 \\
\hline 13-UFVS 2011 & 37.90 & 19.61 & 24.11 & 56.77 & 9.40 \\
\hline 14-M-SOY 8001 & 37.19 & 19.83 & 21.24 & 60.31 & 9.87 \\
\hline 15-UFVS 2001 & 39.71 & 19.12 & 23.14 & 60.17 & 9.30 \\
\hline 16-MG/BR 46 & 38.54 & 19.47 & 24.74 & 58.60 & 9.22 \\
\hline 17-Suprema & 34.25 & 23.01 & 23.28 & 55.89 & 8.59 \\
\hline 18-M-SOY 6101 & 35.96 & 21.90 & 22.01 & 58.77 & 8.62 \\
\hline 19-A7002 & 36.86 & 22.32 & 23.51 & 56.29 & 7.92 \\
\hline 20-PI 417360 & 41.01 & 17.19 & 42.41 & 44.17 & 7.21 \\
\hline 21-CS3032PTA190-5-1 & 43.63 & 17.30 & 22.43 & 62.76 & 9.24 \\
\hline 22-CS3032PTA137-4-10 & 43.55 & 16.48 & 23.06 & 62.08 & 10.30 \\
\hline 23-B3РТА382-2-10 & 43.80 & 17.67 & 25.92 & 60.98 & 8.79 \\
\hline 24-CS3032PTA276-3-4 & 44.31 & 16.84 & 21.45 & 63.13 & 9.02 \\
\hline 25-B3РTA216-1-9 & 43.48 & 18.47 & 24.50 & 61.59 & 9.24 \\
\hline 26-BARC-8 & 45.18 & 18.27 & 21.82 & 62.37 & 7.33 \\
\hline 27-CS3032PTA276-1-2 & 43.75 & 17.13 & 22.67 & 63.18 & 9.37 \\
\hline 28-CS3032PTA167-1-2 & 41.40 & 18.41 & 23.25 & 61.17 & 9.38 \\
\hline 29-B3PTA213-3-4 & 43.23 & 18.50 & 23.66 & 62.38 & 9.50 \\
\hline 30-CS303TNKCA & 38.36 & 20.86 & 22.63 & 61.59 & 5.89 \\
\hline 31-BRSMG 68 & 37.51 & 19.79 & 24.98 & 56.47 & 10.28 \\
\hline 32-PI 181544 & 41.72 & 18.26 & 31.83 & 52.93 & 8.48 \\
\hline 33-PI 371611 & 39.13 & 20.66 & 22.81 & 60.93 & 8.87 \\
\hline 34-PI 371610 & 38.09 & 21.50 & 24.04 & 58.56 & 9.03 \\
\hline 35-CD 225RR & 39.46 & 20.22 & 24.12 & 58.04 & 8.43 \\
\hline 36-CD 224 & 36.91 & 20.71 & 21.98 & 58.41 & 9.20 \\
\hline 37-CD 219RR & 36.61 & 21.61 & 22.76 & 60.71 & 8.78 \\
\hline 38-PI 235347 & 39.54 & 19.48 & 25.51 & 57.90 & 9.34 \\
\hline 39-CD 226RR & 39.62 & 20.13 & 23.81 & 60.10 & 8.87 \\
\hline 40-UFV 20 & 37.53 & 19.67 & 23.74 & 57.94 & 9.86 \\
\hline 41-CD 222 & 36.04 & 20.63 & 22.50 & 61.71 & 9.33 \\
\hline 42-CD01RR8376 & 37.13 & 21.42 & 22.44 & 57.75 & 8.90 \\
\hline 43-CD983321RR & 39.15 & 19.84 & 26.68 & 56.09 & 9.15 \\
\hline 44-BR8014887 & 44.71 & 17.28 & 23.21 & 62.40 & 9.15 \\
\hline 45-CD01RR8384 & 36.85 & 22.91 & 22.46 & 56.71 & 8.93 \\
\hline 46-Monarca & 39.27 & 19.41 & 22.13 & 62.00 & 9.21 \\
\hline 47-UFVTN105AP & 43.11 & 17.45 & 22.99 & 62.92 & 9.02 \\
\hline 48-CD 201 & 41.06 & 19.36 & 23.86 & 61.24 & 8.16 \\
\hline 49-CD2013PTA & 43.36 & 18.31 & 26.02 & 60.87 & 7.10 \\
\hline
\end{tabular}

(another value indicated by the Mojema method) established two main groups, where six accessions are not included in any of the established groups (BARC-8, CD2013PTA, CD01RR8384, CS303TNKCA, PI181544 and PI417360). For this number of groups it is possible to observe the same relationships discussed earlier, which reflects the larger genetic distances of the ungrouped accessions in relation to each group of accessions.

At the bi and three-dimensional projections it was clear the divergence of the accessions PI417360 and PI181544 in relation to the majority. Values of cophenetic correlation, distortion and stress at the bi and three-dimensional projections were equal to 0.96 and 0.9 , 39.72 and $45.68 \%$, and 45.31 and $64.88 \%$; respectively, indicating in both cases low efficacy in representing the distance matrix. Therefore, the projection that best represents the genetic distance relationships is the dendrogram obtained by the UPGMA method.

Other studies about genetic diversity using the Mahalanobis statistics have been made in 


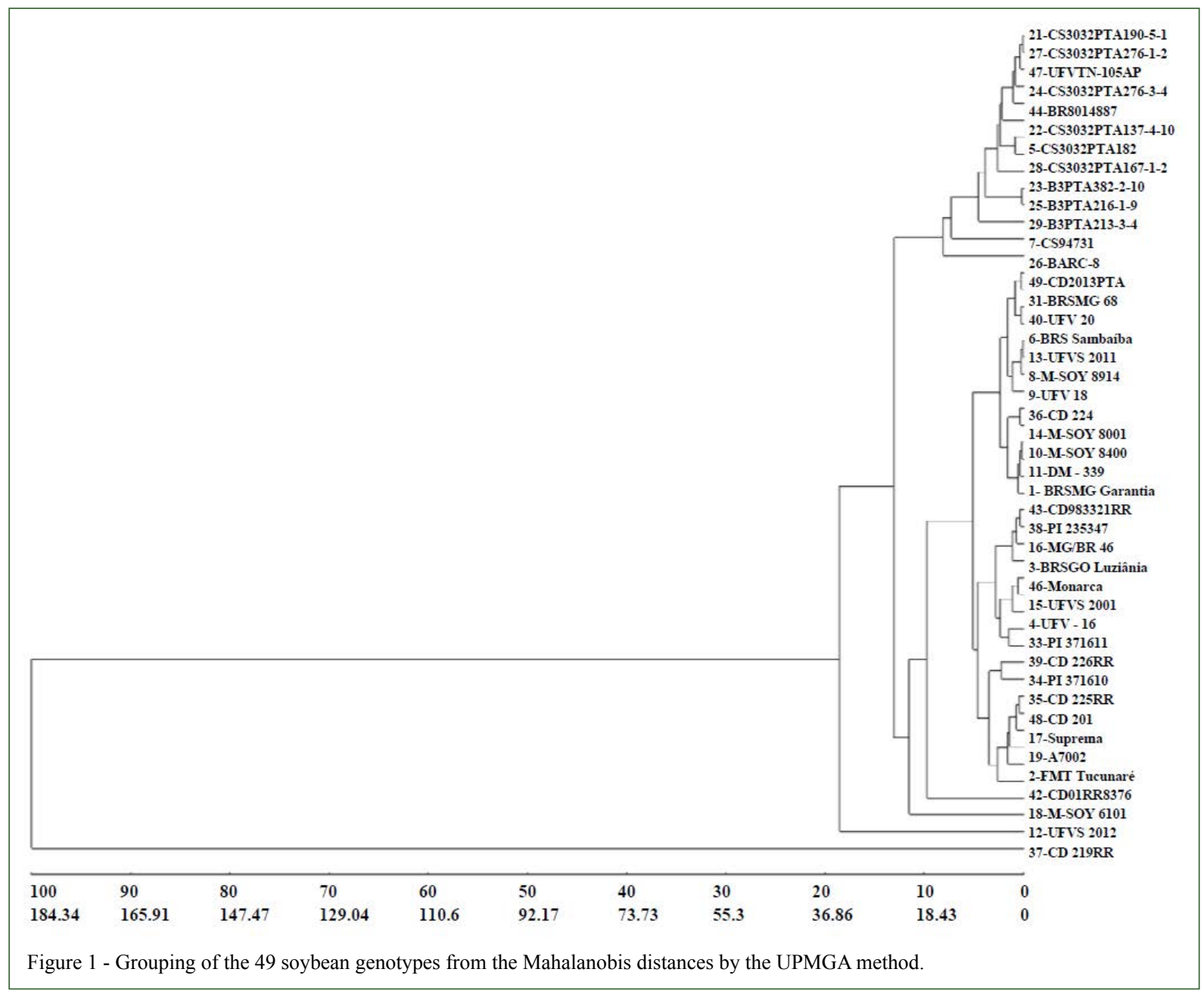

soybean. JAIN et al. (2016) using the Mahanalobis distance observed that 39 soybean genotypes formed 11 distinct groups. PAWAR et al. (2015) using the same measure of distance observed that 80 soybean genotypes formed 14 groups, where the level of genetic diversity was probably lower in relation to the previous study. The most recent studies with Brazilian cultivars, in turn, do not use multivariate analysis. The most recent studies with soybean germoplasm related to genetic diversity use molecular markers (BONATO et al., 2006; VIEIRA et al., 2009; Priolli et al., 2010) and the Malecot's coefficient of relatedness (MIRANDA, 2005; MIRANDA et al., 2007). In these studies the authors reportedlow to moderate diversity in the Brazilian cultivars.

The genetic diversity studies can identify among many accessions the most promising combinations in terms of variability and those less promising for which it is expected a low variability in the crosses, as between accessions of the same group or between accessions with low genetic distance values (ALMEIDA et al., 2011). In this study we indicated as promising in terms of genetic variability the hybridizations involving BARC-8, CD2013PTA, CD01RR8384, CS303TNKCA, PI181544 and PI417360, once such accessions showed larger genetic distances in relation to the majority. So, these genotypes when used in hybridizations in breeding programs may increase the number of desired recombinants and/or be a source of germplasm to create superior genotypic constitutions.

The importance of genetic diversity studies for plant breeding lies in the fact that crosses involving genetically divergent progenitors are most likely in producing genetic variability and heterotic effect. Genetically close progenitors, conversely tend to share alleles in common, causing little complementarity and low vigor in the crossing due to the low level of heterozygosity. In this way,genetic diversity can be considered in the prediction of the potential of 
populations, in the phase of selection of progenitors, avoiding generate populations with low genetic variability (RIAZ et al., 2008; FILHO et al., 2010).

\section{CONCLUSION}

The most genetically divergent pair of genotypes based on the Mahalanobis distance is PI417360/ CD01RR8384, followed by PI417360/B3PTA213-3-4 and PI417360/BARC-8. Based on the average divergence values, the genotypes BARC-8, CD2013PTA, CD01RR8384, CS303TNKCA, PI181544, and PI417360 were the most divergent Among these genotypes we can stand out BARC-8 and CD2013PTA, with protein contents above $43 \%$, and CD01RR8384 and CS303TNKCA, with oil contents above $20 \%$. The use of these genotypes in new crosses should produce genic complementarity and new recombinants to the respective grain traits.

\section{ACKNOWLEDGEMENTS}

We thank Conselho Nacional de Desenvolvimento Científico e Tecnológico $(\mathrm{CNPq})$ for financial support (314899/2014-6)

\section{REFERENCES}

BONATO, A.L.V. et al.Genetic similarity among soybean (Glycine max L. Merrill.) cultivars released in Brazil using AFLP markers. Genetics and Molecular Biology, v.29, p.692-704, 2006. Available from: $<$ http:// www.scielo.br/pdf/gmb/v29n4/32122.pdf $>$. Accessed: June 22, 2015.

FILHO, J.M.C. et al. Heterosis and molecular genetic distances for grain yield in soybeans. Ciência Agrotécnica, v.34, p.940-945, 2010. Available from: <http://www.scielo.br/scielo.php?script=sci arttext\&pid=S1413-70542010000400020 $>$. Accessed: Apr. 28, 2016.

HIROMOTO, D.M.; VELLO, N.A.The genetic base of Brazilian soybean Glycine max L. Merril.cultivars. Brazilian Journal of Genetics, v.9,p.295-306,1986.Availablefrom: $<$ http://www.scielo. br/scielo.php? script $=$ sci_nlinks\&ref $=000101 \&$ pid $=$ S 1415 4757200200020001200011\&lng=en>. Accessed: June 22, 2015.

JAIN, S. et al.Genetic diversity in soybean [Glycine $\max (\mathrm{L}$.) Merrill]. Environment and Ecology, v.34, p.285-287, 2016. Available from: $<$ http://www.cabi.org/cabdirect/FullTextPDF/2016/20163099807. pdf $>$. Accessed: Apr. 28, 2016.
MIRANDA, Z.F.S. et al. Genetic characterization of ninety elite soybean cultivars using coefficient of parentage. Pesquisa Agropecuária Brasileira, v.42, p.363-369, 2007. Available from: <http://www.scielo.br/scielo.php?pid=S0100204X2007000300009\&script $=$ sci_arttext\&tlng $=\mathrm{es}>$. Accessed: Apr. 28, 2016.

MOJEMA, R. Hierarchical grouping method and stopping rules, an evaluation. Computer Journal, v.20, p.359-363, 1977. Available from: <http://comjnl.oxfordjournals.org/content/20/4/359.full.pdf>. Accessed: June 22, 2015.

PAWAR, N. et al. Genetic diversity in soybean germplasm. Soybean Research, v.13, p.84-91, 2015. Available from: $<$ http:// www. soybeanresearch.in/files/2015-issue2.pdf\#page $=88>$. Accessed: Apr. 28, 2016.

PRIOLLI, G.R. et al. Soybean genetic diversity in time and among breeding programs in Brazil. Pesquisa Agropecuária Brasileira, v.39, p.967-975, 2004. Available from: <http://www.scielo.br/pdf/ pab/v39n10/22318.pdf $>$. Accessed: June 22, 2015.

PRIOLLI, G.R. et al. Genetic diversity among Brazilian soybean cultivars based on SSR loci and pedigree data. Brazilian Archives of Biology and Technology, v.53, p.519531, 2010. Available from: <http://www.scielo.br/pdf/babt/ v53n3/a04v53n3.pdf>. Accessed: June 22, 2015. doi: S151689132010000300004 .

RIAZ, A. et al. Genetic diversity of oilseed Brassica napus inbred lines based on sequence-related amplified polymorphism and its relation to hybrid performance. Plant Breeding, v.120, p.411-415, 2008. Available from: <http://onlinelibrary.wiley. com/doi/10.1046/j.1439-0523.2001.00636.x/pdf>. Accessed: Apr. 28, 2016.

SINGH, D.The relative importance of characters affecting genetic divergence. Indian Journal of Genetic and Plant Breeding, v.41, p.237-245, 1981. Available from: <http://www. indianjournals.com/ijor.aspx?target=ijor:ijgpb \&volume $=41 \&$ iss $\mathrm{ue}=2 \&$ article $=010>$. Accessed: June 22, 2015 .

VELLO, N.A. et al.Coefficient of parentage and breeding of Brazilian soybean germplasm. Revista Brasileira de Genética, v.11, p.679-697, 1988. Available from: <http://www.scielo. $\mathrm{br} / \mathrm{scielo}$.php? script $=$ sci nlinks \& $\mathrm{ref}=000169 \& \mathrm{pid}=\mathrm{S} 1516$ $891320100003000040004 \overline{3} \& \operatorname{lng}=$ en $>$. Accessed: June 22, 2015.

VIEIRA, E.S.N. et al. Genetic variability of soybean cultivars obtained through microsatellite markers in agarose gel. Pesquisa Agropecuária Brasileira, v.44, p.1460-1466, 2009. Available from: <http://www.scielo.br/pdf/pab/v44n11/13.pdf $>$. Accessed: June 22, 2015. 